\title{
ABSTRACTS \\ Old nationalism instruments for new local citizenships: a local reaction to global pressure
}

\author{
By Michele Di Benedetto, Brescia
}

According to some authors the nation-state has been functional and a pre-requisite for the structuring and development of the modern market system. Globalization mechanisms are probably making the nation-state a disused and no longer functional structure. The presence of neo-patrimonial states or typical internally weak states in some areas of the world may be an effect of modernity or an effort to provide an answer to global changing scenarios. As do their nemesis, secessionist movements and regional conflictual forces. The answer provided by neo-patrimonial states to the globalisation pressure can be a short-sighted one: the mechanisms inducted within those states are long term ones, not only in terms of secessionist movements based on the same premises, but, also through those, as an influence on all and each individual. An inclusion-exclusion mechanism built on a logic which is merely founded on access to resources, being it a profitable or a sustaining one, and on exclusionary mechanisms derived by such logic, is set to produce unequal and close communities and to force on the retreat a general idea of citizenship.

\section{Potential and Limits of International Election Observation in Fledgling Democracies: The Case of Uzbekistan}

\section{By Christina Binder, Wien}

This contribution proposes to examine potential and limits of international election observation and assessment in fledgling democracies. This will be done by taking the example of the OSCE/ODIHR election assessment mission to the December 2009 parliamentary elections in Uzbekistan.

First, an overview of the different formats of election observation missions is given and the the relevant international electoral standards as contained in major human rights instruments (eg Article 25 CCPR) as well as - in the regional context of the OSCE - in the 1990 Copenhagen document are discussed. Then, potential and limits of international election observation and assessment are examined from a general perspective.

Given the Uzbek failure to comply with key international electoral standards and commitments, it is finally discussed whether there is an added value of international election observation in Uzbekistan. Based on an assessment as to what extent the OSCE/ODIHR election assessment mission of 2009 was able to contribute to the improvement of the 
Uzbek electoral process, it is argued that it remains useful - under certain conditions - to engage in (limited) election observation and assessment even in countries as Uzbekistan.

\section{Corruption in developing countries: Reduction through democratization? - An empirical analysis}

By Nadja Memmer, Brisbane

Corruption is one of the most important reasons why many people in developing countries do not receive health care and education. To break this vicious circle of poverty the World Bank postulates Good Governance which is said to be the implementation of liberal democracies. But in how far do liberal-democratic structures influence corruption in developing countries? The article starts with a theoretical introduction that describes the connection between Good Governance, liberal democracy and corruption in developing countries. Based on these findings current data on Freedom House and Transparency International will be identified as accurate measures of liberal-democratic structures and corruption in developing countries. Given these indicators the main part explores the statistical relationship between liberal-democratic structures and corruption in developing countries using the methods of linear regression analysis. In conclusion, liberal-democratic structures do affect corruption in developing countries but the relationship is complex and has to be discussed critically. Accordingly, Good Governance should not be seen as a one and only solution suitable for all developing countries. Instead, it is recommended to carry out in-depth case studies which point out the relevant criteria for an efficient corruption reduction policy for each affected country.

\section{A bouquet from Kenya - at what price? The Kenyan labor law and its implementation on the flower plantations}

By Katrin Merhof, Konstanz

Kenya is one of the top five exporters of cut flowers worldwide. One out of every three roses sold in Europe comes from the East African country; the largest end consumer of Kenyan cut flowers is Germany. But why are these flowers whose cultivation is so demanding available at such low prices in our supermarkets? One factor certainly is the Kenyan climate that enables inexpensive production of flowers, yet the main reason is undoubtedly the availability of cheap manpower. Working conditions on a flower plantation in Kenya are characterized by poor health and safety conditions, and low levels of union representation, where laborers are employed on temporary contracts, receive low wages, and are expected to work overtime with no extra benefits. Women, representing the clear majority of flower workers, suffer in addition from widespread discrimination and sexual harassment at work. 
In this article, the author is examining the legal situation of the workers and the implementation, or rather lack of implementation of the applicable labor law in the Kenyan horticulture industry.

\section{Globalisation and international insertion of Africa: The anthropology of a recused dynamic}

\section{By Jean Njoya, Yaounde}

This paper renews the problem of Africa's international presence, presence which for a long time has been contested by the Path dependence theory in international relations relegating Africa to the periphery of the world linking its destiny to that of the Western World. This thesis is anthropologically and historically erroneous for the simple reason that colonial era is an impertinent sign of Africa's presence in the international scene; rather, a long time before one could enable an objective appropriate restitution of Africa's implication in the world which began even before the colonial era (transsaharian trade, establishment of Indonesian colonies in Madagascar, regular trade with India, the regions of the Persian Golf and the Mediterranean). 